\title{
Survey on Primary and Middle School Teachers' In-service Learning Demand in Minority Area of Northern Guangdong
}

\author{
Jianlan Wang, Lina Zhang, Xiaoma Xiao, Chongmin Liu, Houlei Teng \\ Shaoguan University, Shaoguan, 512005, China
}

Keywords: Northern Guangdong; Minority; Primary and middle school teachers; Learning demand; Survey

\begin{abstract}
The research group carries out a survey on 12 schools in minority area of northern Guangdong; the questionnaire involves 734 primary and middle school teachers, and the teachers of minority account for 34\%. Through comparison on nationality, gender, education background, primary and middle school in terms of teachers' training frequency, time, content, form, level, expense, trainers, and influence factors, the results shows that there is great difference between middle school teachers and primary school teachers, and great difference between teachers of bachelor degree and teachers of junior college degree, followed by the difference between Han teachers and teachers of minority; there is little difference between male and female teachers.
\end{abstract}

\section{Introduction}

The in-service training is an important means for teacher professionalization. The research group selects the teachers of 12 primary and middle schools with minority inhabited in Ruyuan Yao Autonomous County of Shaoguan City, Shixing County of Shaoguan City, Liangshan Zhuang Autonomous County of Qingyuan City, and Liannan Yao Autonomous County of Qingyuan City of northern Guangdong as main survey objects, and adopts questionnaire survey and interview survey. There are totally 734 effective questionnaire recovered, and the teachers of minority and Han nationality account for $33.8 \%$ and $66.2 \%$ respectively, the teachers of primary schools and middle schools account for $34.7 \%$ and $65.3 \%$ respectively, the teachers of bachelor degree and junior college degree account for $61.7 \%$ and $33.3 \%$ respectively, and the female and male teachers account for $59.4 \%$ and $40.6 \%$ respectively. The surveyed objects are leaders of local education bureau and schools as well as teachers, 50 people in total, and the interview is made through individual and team form. The data of questionnaire is handled via SPSS software system. The different statistical result in expression, such as more or less, is the significant difference in statistics.

\section{Current situation and problems}

\section{Training frequency and time}

As a whole, the teachers accept one or two trainings which continues for 1-2 weeks on a yearly basis on average. According to the result of data statistics, most of teachers of minority annually accept 1-2 trainings compared to teachers of Han nationality, and most of primary school teachers and teachers of junior college degree hope to annually join 1-2 trainings compared to middle school teachers and teachers of bachelor degree.

The result of data statistics shows that more primary school teachers and teachers of junior college degree accept the training which continues for not more than 1 week than middle school teachers and teachers of junior college degree, and more primary school teachers and teachers of junior college degree hope to accept the training which continues for not more than 1 week than middle school teachers and teachers of junior college degree.

The survey result shows that the training time that the teachers think suitable is "teaching and research activity time at ordinary times", "winter and summer vacation”, and "two-day weekend", and the number of teachers who think that the above time is suitable accounts for $80 \%, 18 \%$, and $2 \%$ 
respectively. However, most of teachers of junior college degree think that the winter and summer vacation is suitable, and most of teachers of bachelor degree think that it is suitable to carry out training in teaching and research activity time at ordinary times.

\section{Training content}

In this survey, we have adopted multiple-choice form to know the training content the teachers accept, mainly including professional skills, computer teaching, multimedia application, professional theory, and education science; the number of teachers who accept above contents account for $68.2 \%$, $58.9 \%, 57.3 \%$, and $42.3 \%$ respectively.

The teachers think that the knowledge they most need in teaching includes teaching skills, subjects, curriculum reform concept, education technology and information technology, psychology, and education science, and the number of teachers account for $73.1 \%, 45.6 \%$, 35.6\%, 33.4\%, 32.3\%, and $20.2 \%$ respectively. Compared to teachers of Han nationality and middle school teachers, most of teachers of minority and primary school teachers think that the most necessary knowledge is professional knowledge; compared to male teachers, most of female teachers think that the most necessary knowledge is teaching skills; compared to middle school teachers, most of primary school teachers think that the most necessary knowledge is education technology and information technology.

The teachers think that the skills they most need to improve include teaching design, scientific research, classroom activity design, courseware making, course resource development, teaching reflection, classroom control, and verbal expression, etc., and the number of teachers account for $36.8 \%$, 35.2\%, 33.8\%, 31.1\%, 28.3\%, 24.8\%, 23.1\%, and 20.5\% respectively. Compared to teachers of Han nationality, most of teachers of minority think that the skill they most need to improve the teaching reflection ability. The difference between teachers of different degree and between primary school teachers and middle school teachers can be seen in Table 1.

According to the data in Table, it can be seen that most of middle school teachers and teachers of bachelor degree think that the skills they most need to improve include the scientific research ability and course resource development ability, and most of primary school teachers and teachers of junior college degree think that the skill they most need to improve is courseware making ability.

Table 1. Comparison on skills the teachers most need to improve (percentage of number of teachers)

\begin{tabular}{|c|c|c|c|c|c|c|}
\hline Comparison & $\begin{array}{l}\text { Scientific } \\
\text { research }\end{array}$ & t-test & $\begin{array}{l}\text { Courseware } \\
\text { resource } \\
\text { development }\end{array}$ & t-test & $\begin{array}{c}\text { Coursewar } \\
\text { e making }\end{array}$ & t-test \\
\hline $\begin{array}{c}\text { Primary } \\
\text { school } \\
\text { teachers }\end{array}$ & 22.4 & $\mathrm{t}=-4.506$ & 22.8 & $\mathrm{t}=-2.375$ & 40.9 & $t=3.946$ \\
\hline $\begin{array}{c}\text { Middle } \\
\text { school } \\
\text { teachers }\end{array}$ & 41.2 & $\begin{array}{c}\mathrm{P}=0.000 \\
*\end{array}$ & 34.4 & $\begin{array}{c}\mathrm{P}=0.018 \\
*\end{array}$ & 26.3 & $\mathrm{P}=0.000$ * \\
\hline $\begin{array}{c}\text { Teachers of } \\
\text { junior } \\
\text { college } \\
\text { degree }\end{array}$ & 22.6 & $\mathrm{t}=4.685$ & 20.3 & $\mathrm{t}=3.412$ & 40.7 & $\mathrm{t}=-3.889$ \\
\hline $\begin{array}{c}\text { Teachers of } \\
\text { bachelor } \\
\text { degree }\end{array}$ & 44.1 & $\begin{array}{c}\mathrm{P}=0.009 \\
*\end{array}$ & 34.4 & $\begin{array}{c}\mathrm{P}=0.001 \\
*\end{array}$ & 25.7 & $\mathrm{P}=0.000$ * \\
\hline
\end{tabular}

\section{$\mathrm{P} \leq 0.05 *$ significant difference}

Through this survey, we also have known the condition about teachers' application of multimedia equipments to assist the teaching, and the teachers who "rarely", "often", "don't" use multimedia equipments to assist the teaching account for $48.7 \%, 45.5 \%$, and $5.8 \%$, and the teachers who feel "fluent" upon using multimedia equipments to assist the teaching account for $56.3 \%$, and the teachers who feel "slightly difficult" and "very difficult" account for 38.1\% and 5.7\% respectively. The data 
in Table 2 shows the comparative difference in primary and middle school teachers and teachers of different education background. Most of middle school teachers and teachers of bachelor degree "often" use multimedia equipments to assist the teaching, and most of them feel "fluent" in the use process.

Table 2. Comparison in frequency and effect of teachers' application of multimedia equipments to assist the teaching (percentage of number of teachers)

\begin{tabular}{|c|c|c|c|c|c|c|c|c|}
\hline Comparison & Often & Rarely & No & t-test & Fluent & $\begin{array}{l}\text { Slightly } \\
\text { difficult }\end{array}$ & $\begin{array}{c}\text { Very } \\
\text { difficult }\end{array}$ & t-test \\
\hline $\begin{array}{l}\text { Primary } \\
\text { school } \\
\text { teachers }\end{array}$ & 37.1 & 55.6 & 7.3 & $\mathrm{t}=2.720$ & 40.9 & 50.4 & 8.6 & $\mathrm{t}=5.891$ \\
\hline $\begin{array}{c}\text { Middle } \\
\text { school } \\
\text { teachers }\end{array}$ & 49.5 & 45.4 & 5.1 & $\begin{array}{l}\mathrm{P}=0.007 \\
*\end{array}$ & 63.7 & 32 & 3.7 & $\begin{array}{l}\mathrm{P}=0.007 \\
*\end{array}$ \\
\hline $\begin{array}{l}\text { Teachers of } \\
\text { junior } \\
\text { college } \\
\text { degree }\end{array}$ & 28.4 & 63 & 8.5 & $\mathrm{t}=-5.673$ & 37.3 & 56.6 & 6.1 & $\mathrm{t}=-7.090$ \\
\hline $\begin{array}{c}\text { Teachers of } \\
\text { bachelor } \\
\text { degree }\end{array}$ & 56.1 & 39.3 & 4.5 & $\begin{array}{l}\mathrm{P}=0.000 \\
*\end{array}$ & 68.7 & 27.6 & 3.7 & $\begin{array}{l}\mathrm{P}=0.000 \\
*\end{array}$ \\
\hline
\end{tabular}

\section{Training form}

Through statistical comparison, it is found that more teachers of Han nationality participate in the school-based concentrated remote education than teachers of minority; more primary school teachers hope to accept school-based training than middle school teachers; more middle school teachers hope to accept mid-career studies than primary school teachers; more female teachers hope to accept school-based concentrated training than male teachers.

The effective means for teachers' improving professional ability mainly include off-campus teaching observation (attending a lesson, observing a lesson, reviewing a lesson), experts' guidance, school teaching and researching activity, mid-career studies, self-reflection, and reading professional books and periodicals, and the number of teachers account for $80.7 \%, 43.3 \%$, 34.7\%, 33.6\%, 26.8\%, and $25.1 \%$ respectively. More middle school teachers think that the "off-campus teaching observation" is the effective means to improve professional ability than primary school teachers; more teachers of bachelor degree think that the "experts' guidance" is the effective means than teachers of junior college degree; more teachers of Han nationality and bachelor and middle school teachers think that the "mid-career studies" is the effective means than teachers of minority and junior college degree and primary school teachers; more teachers of Han nationality and bachelor and middle school teachers think that the "self-reflection" is the effective means than teachers of minority and junior college degree and primary school teachers; more teachers of bachelor degree, middle school teachers, and female teachers think that "reading professional books and periodicals" is the effective means than teachers of junior college degree, primary school teachers, and male teachers.

Furthermore, we know through survey that $42.7 \%$, 35.8\%, and $21.6 \%$ of teachers hold the attitude of "support", "no care", and "opposition" in case of implementation of regular flow between urban and rural teachers. More teachers of minority, male teachers, and middle school teachers hold the attitude of "support" than teachers of Han nationality, female teachers, and primary school teachers.

In the actual work, the teachers mainly solve the teaching problems through query on the internet, followed by consultation to colleagues, looking up books and newspapers, and consultation to experts, and the number of teachers account for $72.2 \%, 66.7 \%$, 35.7\%, and 5.6\% respectively. More primary school teachers select to "consult to colleagues" than middle school teachers; more teachers of minority and bachelor degree select to "make query on the internet" than teachers of Han nationality 
and junior college degree. The primary school teachers' rare query on the internet is consistent with their difficulty in using multimedia equipments to assist the teaching.

\section{Training level and trainers}

The survey data reflects that more teachers of Han nationality, middle school teachers, and teachers of bachelor participate in provincial-level training, more teachers of minority and junior college degree participate in county-level training, and more primary school teachers and female teachers participate in county-level and school-level training.

The trainers that the teachers most hope to accept are excellent front-line teachers, experts, special-class teachers, instructors and researchers, and the number of teachers account for $54.7 \%$, $29.4 \%, 9 \%$, and $6.9 \%$ respectively; more than half of teachers think that the excellent front-line teachers are ideal trainer rather than "experts". More middle school teachers and teachers of Han nationality think that the "excellent front-line teachers" are ideal trainer, and more primary school teachers and teachers of minority think that the "experts" are ideal trainer.

\section{Training expense and evaluation}

As for the training expense of further education, 66.3\% of schools agree to pay the training expense, $28.8 \%$ of schools agree to carry out training but require that the training expense is borne by teachers themselves, and $15.8 \%$ of teachers make use of spare time and self-raised funds to participate in training. The statistical value in Table 3 shows significant difference in teachers of different education background and primary and middle school teachers. This survey shows that most of primary school teachers and teachers of junior college degree participate in the training under the school funding; in consideration of expense, some schools use local resources and make local arrangement; the middle school teachers and teachers of bachelor degree who undertake their own training expense have higher requirement for training level, which is directly related and identical to the situation that that middle school teachers and teachers of bachelor degree accept a high level of training.

Table 3. Comparison in training expenditure of further education

\begin{tabular}{|c|c|c|c|c|}
\hline Comparison \% & $\begin{array}{l}\text { The schools agree } \\
\text { the training and } \\
\text { bear training } \\
\text { expense }\end{array}$ & t-test & $\begin{array}{l}\text { The schools agree the } \\
\text { training but the teachers } \\
\text { bear their training } \\
\text { expense }\end{array}$ & t-test \\
\hline $\begin{array}{l}\text { Primary } \\
\text { school } \\
\text { teachers }\end{array}$ & 72 & $\mathrm{t}=2.416$ & 21.1 & $\mathrm{t}=-3.247$ \\
\hline $\begin{array}{l}\text { Middle school } \\
\text { teachers }\end{array}$ & 63.8 & $\begin{array}{l}\mathrm{P}=0.016 \\
*\end{array}$ & 32.5 & $\begin{array}{l}\mathrm{P}=0.001 \\
*\end{array}$ \\
\hline $\begin{array}{l}\text { Teachers of } \\
\text { junior college } \\
\text { degree }\end{array}$ & 71.9 & $\mathrm{t}=-2.117$ & 23.8 & $\mathrm{t}=2.442$ \\
\hline $\begin{array}{c}\text { Teachers of } \\
\text { bachelor } \\
\text { degree }\end{array}$ & 63.4 & $\begin{array}{l}\mathrm{P}=0.035 \\
*\end{array}$ & 33.3 & $\begin{array}{l}\mathrm{P}=0.015 \\
*\end{array}$ \\
\hline
\end{tabular}

$\mathrm{P} \leq 0.05 *$ significant difference

In terms of opinion on training evaluation, $46.89 \%$ of teachers think that the evaluation is "necessary", 31.4\% of teachers show "no care", and 21.8\% of teachers thinks "unnecessary". More teachers of minority think necessary, and more teachers of Han nationality think unnecessary. The proportion of trained teachers who show "no care" and think "necessary" reflects the effect of current training evaluation.

The teachers think that the most effective ways of evaluation include submission of teaching case or on-site presentation, submission of papers or training experience, establishing documentary file based on training classroom expression, and exam, and the number of teachers account for 35.8\%, 
$33 \%, 24.8 \%$, and $6.4 \%$ respectively; the exam is the most unpopular way of training evaluation. According to the interview, some evaluation adopts easy exam; if the closed-book exam is required but the discipline is not serious, someone often regard it as open-book exam so that the exam result is unfair; besides, the exam focuses on theory and breaks away from actual teaching, which makes many teachers feel frustrated and even antipathic.

\section{Factors influencing the training}

The main factors which influence the teachers to participate in training include heavy teaching task, no actual training effect, no corresponding incentive means, no interest due to passive participation, and weak learning atmosphere, accounting for $44.5 \%, 27.7 \%$, 25.4\%, 11.6\%, and 6\% respectively. Most of factors influence the teachers to participate in training belong to objective reason, and the most prominent factor is the heavy teaching task. Compared to primary school teachers, more middle school teachers think that "no actual training effect" is the primary factor which influences the teachers to participate in training.

The teaching load influences the training effect to certain degree. According to the comparison on statistical result, the number of students in most of classes under the charge of primary school teachers and teachers of junior college degree is less than 50, and the number of students in most of classes under the charge of middle school teachers and teachers of bachelor degree is more than 50 . As for classes under the teachers of minority, the number is 50-59; as for classes under the charge of Han nationality, the number is more than 60 .

In terms of suitable number of students, more female teachers, primary school teachers, and teachers of junior college degree think that it is suitable to be controlled within 30, more teachers of minority think that it is suitable to be controlled within 40 , more teachers of bachelor degree and male teachers think it is suitable to be controlled within 30-50, and more teachers of Han nationality and middle school teachers think it is suitable to be controlled within 40-50.

Through this survey, it is know that $1 \%$ of teachers have a per capita one-week lessons-giving amount of below 4 lessons, 11.8\% have an amount of 5-8 lessons, 45.8\% have an amount of 9-12 lessons, 32.6\% have an amount of 13-16 lessons, and 8.9\% have an amount of 17 lessons. Through comparison on statistical result, more male teachers give 5-8 lessons, more middle school teachers give 9-12 lessons, and more primary school teachers and female teachers give more than 13 lessons.

As for teachers working time in one day, $43.6 \%$ have $6-8$ hours, $42.4 \%$ have $9-11$ hours, $11.4 \%$ have more than 12 hours, $2.2 \%$ have $3-5$ hours, and $0.4 \%$ have less than 2 hours. Through this survey, we have known that almost $80 \%$ of teachers give $2-3$ lessons on a daily basis on average, $86 \%$ have a daily working time of 8.5 hours; except for the time of giving lessons, the time they use for preparing lessons, instruction after class, teaching discussion, and communication with students is about 7 hours. 43.5\% of teachers feel "too tight" for their work, $46.4 \%$ feel "slightly tight", 9.3\% feel "common", and $0.8 \%$ feel "easy" and "very easy". Through comparison in statistical result, the teachers of minority, primary school teachers, and teachers of junior college degree have a working time of 6-8 hours at most, and the teachers of Han nationality, middle school teachers, and teachers of bachelor degree have a working time of more than 9 hours at most.

In theory, the ideal number of students is about 35; the survey result shows that the number of students in most classes is about 50, and most teachers think that the suitable number shall be 30 . In fact, the excessively few number of students will result in tight teacher formation, and improvement in teaching cost; the excessively large number of students is not good for management and teacher-student communication, which reduces teaching effect. In order to solve this contradiction, we shall firstly consider the possible education investment by local government, and then consider the quantity of teachers, and then determine number of students according to scientific quota.

\section{Conclusion and suggestion}

1). According to this survey result, in terms of education background, most of primary school teachers have junior college degree, and most of middle school teachers have bachelor degree; therefore, the two kinds of difference shown in this survey can be summarized as one difference, that 
is, difference between primary school teachers and middle school teachers, or difference between teachers of junior college degree or teachers of bachelor degree.

2). As for the content, form, and method of teaching training, we shall consider the actual condition of trainees. The trainers shall be good at digging the suiting point between training content and trainees, and the training content shall be combined with teachers' teaching activity. The teachers generally pay attention to improving their professional skills, especially teaching skills; in terms of theoretical learning, the teachers focus on subjects, thus the training content shall be closely combined with the trainees' teaching professional skills and necessary knowledge ability to improve the trainees' ability.

3). The managers shall mitigate primary and middle school teachers' teaching burden, especially middle school teachers' teaching load so that the teachers can spend more energy in training learning. Besides, it is required to expand investment and arrange sufficient teachers.

4). The organization and management of teacher training shall be made according to certain rules; it is required to establish and perfect the training evaluation mechanism, enhance the quality control on training activity process, and establish perfect training evaluation system to guarantee the training quality.

\section{Acknowledgments}

This paper is one of the achievements of the project funded by Lingnan Institute of Research "Survey Research on Basic Education in Minority Area of Northern Guangdong” (Project No.: LN2011JC02).

\section{References}

[1] Wang Jianlang et al.: Current Situation of Minority Culture Inheritance in School Education and Countermeasures - Based on Survey on Minority Area of Northern Guangdong, Journal of The Chinese Society of Education, 2014 (4). 